\title{
LONGER EFL VOCABULARY RETENTION: LEARNING IN CONTEXT OR IN ISOLATION?
}

\author{
Hesthi Herusatoto
}

Email: hesty_h3@yahoo.com

Sekolah Tinggi Bahasa Asing (STBA) LIA Yogyakarta

Alamat korespondensi: Jl. Lingkar Utara, Pandeansari Blok IV/8 Condongcatur, Depok

Sleman, Yogyakarta 55283

\begin{abstract}
This research aims to examine the effectiveness of two different vocabulary learning strategies on vocabulary retention. The first is learning words in isolation in which learners learn new words and their meanings presented in the form of word lists; and the second is learning words from context in which learners use clues in sentences in texts to generate meanings for the target words. In the instruction sessions, a group of senior high school students learning vocabulary in isolation was presented with a number of words in English and their meanings. Their task was to say and repeat the words and their meanings several times as they attempted to learn the new words and their meanings. The group of students learning words from context was presented with some texts containing the target words and was asked to find out the meanings of the target words by using clues in the texts. Recall tests were administered twice, a week and two weeks after the instruction sessions. For word retention, results of the recall tests revealed that learning words in isolation appeared to be more effective than learning words from context. Students learning words in isolation retained the target words and the meanings better than those in the other group.
\end{abstract}

\section{Keywords}

Word Lists, Context, Vocabulary, Retention

\section{Introduction}

A number of researchers have tried to explore problems concerning foreign vocabulary acquisition. Research comparing various kinds of vocabulary learning, two of which are learning words in context and learning words in isolation, was conducted with the purpose of finding out the most effective approach.

Some language professionals, such as Judd (1978), Krashen (1982, 1989), Shcouten-van Parreren (1985, 1989), McCarthy (1990), and Oxford and Scarcella (1994) believe that learning words by inferring meaning from context tends to lead to a better retention than learning in isolation (word lists). Referring to other previous writers, Judd (1978) points out that "most people agree that vocabulary should be taught in context" (quoted in Nation, 1982: 22). Other views (Seibert, 1930; Nemko, 1984), however, consider that the word pairs approach might result in longer retention.

The aim of the present study is to examine the two vocabulary learning approaches, i.e. learning words in context and learning words in isolation (word pairs), with the purpose of comparing vocabulary retention as a consequence of the two approaches.

Learning words from context involves learners' ability to infer or guess the meaning of words from context. Thus, to employ this method, learners are required to have skills in guessing the meaning of words. Learning words in isolation might be in the form of word lists, flashcards, and dictionary use (Oxford \& Scarcella, 1994). Word lists, which will be used in this study, may comprise learning lists of word forms and their meanings which are usually presented in word pairs. As Nation (1982: 16) states "when vocabulary is learned in lists, an item often consists of a pair of words, namely a foreign word form and its meaning which is usually a translation. Thus, one item in a list is referred to as a word pair".

A study by Mondria and Wit-De Boer (1991) highlights Schouten-van Parreren's idea which focuses on the receptive acquisition of words. "...words are best learned through reading, in which the process of inferring the meaning of words from the context is thought to have a clearly positive effect on retention" (Mondria \& Wit-De Boer, 1991: 250). Furthermore, according to 
Schouten-van Parreren, the context used for the purpose of gaining word retention needs to be "pregnant", i.e. offering "ample clues for finding the meaning of the new word" (Mondria \& Wit-De Boer, 1991: 252). Therefore, learners need to guess the meaning of words both from the context and the word-form. However, guessing words is required to be correct as guessing wrongly might result in having the wrong meaning remaining in the mind. Mondria and Wit-De Boer's study (1991), however, concludes that the use of pregnant context does not affect the improvement of retention. It improves the guessing skills though. The words which are correctly guessed more often with the use of pregnant context would be easily forgotten because after having successfully guessed the meaning, the learners in their study believe that they knew the words already which then leads them to reduce their effort to imprint the words. 


\section{Conclusion}

For Indonesian learners of English, the results of the research indicates that learning vocabulary in isolation or using word lists is more effective than learning vocabulary from context. The recall tests used to measure the vocabulary retention statistically demonstrate that learning vocabulary in isolation in which learners learnt by repeating new words and their meanings is superior to learning words from context in which learners used clues in sentences to generate meanings. The descriptive statistic indicates that the means of the second recall test of the students who learnt vocabulary from context declines sharper when compared to the other group of students.

Indeed, learning new words presented with their meanings (the mother tongue equivalents) seems to be easier than that of generating the meanings of the new words from context. This is because the former requires the learners to say the words aloud provided with the meanings, which according to Seibert (in Ellis and Beaton, 1993: 562) leads to faster learning with better retention than doing silent repetition of the word lists. The latter technique, however, is not inferior at all. Learners certainly need to make more effort in learning the target words as they need to work out the meanings of the new words by themselves by using any possible clues in the sentences. In fact, this technique has its own benefits. It gives the learners more chances to learn other new language items since the context can offer extra linguistic or semantic knowledge of the words being learnt.

\section{REFERENCES}

Benthuysen, Robert Van. 2002. Explicit Vocabulary Instruction: Using a Word List to Focus Attention. http://cicero.u-bunkyo.ac.jp/lib/kiyo/fsell2002/89-96.pdf. 25 August 2007.

Ellis, N.C., \& A. Beaton. 1993. "Psycholinguistic Determinants of Foreign Language Vocabulary Learning". Language Learning, 43 (4), 559-617.

Gu, Yongqi \& Robert Keith Johnson. 1996. "Vocabulary Learning Strategies and Language Learning Outcomes." Language Learning, 46 (4), 643-679.

Gu, Yongqi. 2003. "Vocabulary Learning in a Second Language: Person, Task, Context and Strategies". TESL-EJ, Vol. 7 No. 2. http://www-writing.berkeley.edu/TESL-EJ/ej26/a4.html. 25 August 2007.

Honeyfield, John. 1997. "Word Frequency and the Importance of Context in Vocabulary Learning". RELC Journal, 8 (2), 35-42.

Mondria, Jan-Arjen \& Marijke Wit-De Boer. 1991. "The Effects of Contextual Richness on the Guessability and the Retention of Words in a Foreign Language". Applied Linguistics, 12 (3), 249-266.

Nation, I.S.P. 1982. "Beginning to Learn Foreign Vocabulary: A Review of the Research". RELC Journal, 13 (1), 14-36.

Nation, I.S. P. 2001. Learning Vocabulary in Another Language. Cambridge: Cambridge University Press.

Oxford, Rebecca L. \& Robin C Scarcella. 1994. "Second Language Vocabulary Learning among Adults: State of the Art in Vocabulary Instruction". System, 22 (2), 231-243.

Qian, David D. 1996. "ESL Vocabulary Acquisition: Contextualization and Decontextualization". The Canadian Modern Language Review, 53 (1), 120-142.

Schmitt, Norbert. 2000. Vocabulary in Language Teaching. Cambridge: Cambridge University Press. 